There is no unique solution. We would recommend the following:

(i) A system of risk classification should be devised and all investment products should be given a risk rating,

(ii) Illustrations should be shown on two alternative investment assumptions to convey the inherent uncertainty of final outcome,

(iii) The two assumptions should be very wide, $5 \%$ and $10 \%$ for life products and $7 \frac{1}{2} \%$ and $15 \%$ for pension products are recommended under current conditions.

(iv) A corresponding rate of inflation (10\% price, $12 \%$ earnings) must be shown,

(v) If past performance is being used, it is best to use externally published league tables. If it is to be an integral part of the illustration basis this measure must relate to a comparable product. The return must be expressed as an overall yield on the gross premiums invested and the corresponding average annual rate of price inflation must be shown,

(vi) Specific guidance should be given to appointed actuaries not to overdistribute simply to inflate league table position and possibly to add a note along the following lines whenever past performance is used in the sales process:

'Although past performance is no guide to the future, the Company has been advised by its Actuary that given similar investment conditions a similar result can be achieved for the current generation of new policyholders'-assuming that it can honestly say so,

(vii) Avoid spurious accuracy by sensibly rounding figures.

\title{
NORTH AMERICAN CASUALTY BUSINESS \\ WRITTEN IN THE LONDON MARKET
}

\author{
BY JOHN P. RYAN
}

(Synopsis of a paper presented to the Society on 18 March 1986)

THIS paper is an introduction to the actuarial aspects of U.S.A. Casualty business written in the London Market. It provides an indication of the type of problems encountered and how the business differs from that in other fields perhaps more familiar to non-life actuaries in the U.K. Whilst premium rating and claims reserving are central to the discussion, particular techniques are not described in detail. Various aspects of the legal, fiscal and institutional facets of the market are described with the aim of giving the background knowledge essential for effective data analysis for rating and reserving.

The key difficulties are the especially long tails of the business and the relative short experiences of companies and syndicates writing the business. For many 
covers the length of the tail can be at least 25 years and a large number of underwriters only began writing business in the 1970's and 1980's.

A company's own data, when broken down into homogeneous risk groups, is rarely large enough for full credibility. The actuary is compelled to use additional data from industry sources. The paper describes the availability and characteristics of data published by the Reinsurance Association of America (RAA), Best's, National Council for Compensation Insurance (NCCI) and Insurance Services Office (ISO). It is also noted that the information filed by individual companies when applying for a rate revision is publicly available in each state. Many of these applications contain supporting data collected on a countrywide basis. The role of judgment in choosing the appropriate U.S.A. data for an investigation of London market business is emphasized. Examples of the data available and indications of the consequences of inappropriate choices are given.

In addition it is important to make allowances for the impact of changes in the mix and handling of London market business, when compared to the overall U.S.A. business. Particularly important factors are faster reporting of claims, more conservative case estimation, the impact of reinsurance programmes, policy limits, differences in layer and attachment points, introduction of a limited number of reinstatements. The preference is for scanty and homogeneous data rather than larger but heterogenous groupings. The estimation of trending factors presents less of a problem for the market than is popularly believed.

The problems of reserving are discussed. The Bornhuetter-Ferguson method of claims reserving is advocated as a 'standard' method. The most appropriate distribution for rating is the log normal with suitable adjustments for nuisance claims and policy limits. Straight-forward simulation exercises are usually sufficient to check this distributional assumption and the effect of high claim severity, the long time to settlement and the high trend of claims costs, together with changing limits for deductable levels and attachment points on claims experienced.

The later sections describe the legal and institutional factors which impact upon the reported experience and which are important for the judgmental aspects of reserving and rating.

The methods of placing business are outlined, The roles of U.S.A. brokers, agents and insurers and their relationships with the 'actors' in the London market are described. It is important to understand the terms under which covers are issued, but the variety of contracts offered and the lack of detail available to the insurer make this difficult. Automobile cover offered in the London market is mainly bodily injury liability. The cover and rating structure is very different to that offered in Europe, e.g. the absence of no claims discounts, cover often on a no fault basis. A good summary on a State by State basis is published by the American Insurance Association. Other personal insurances are only a minor feature of the London market. The coverages offered under Commercial General Liability contracts are outlined. The other major component of the London market is Professional Indemnity Liability cover. The cover offered to different 
groups, e.g. doctors and physicians, architects, bankers, are described. The nature of umbrella covers which provide liability cover in excess of all other such covers held by the insured are described. These covers are an important part of the London market.

Regulation of insurance is on a State by State basis with large variation in the regulations and their implementation between States. These regulations can affect all aspects of the business written; rating, reserving, solvency. Restrictions on the placement of primary business can have a big influence on the mix of business offered in the London market.

A vital distinction in the cover offered for professional liability business is between that written on an occurrence basis and that written on a claims made basis. From the insured's point of view an occurrence basis - all eligible claims arising from incidents during the period of cover are met-is to be preferred. However from an underwriting viewpoint, a claims-made basis - only eligible claims notified during the period of cover and the following short reporting period are met - presents fewer rating and reserving problems. It is essential that the exact basis of the business is known before attempting any actuarial investigations. The recent tendency in the London market has been only to accept business on a claims-made basis. Such a situation is influenced by the state of the market and may not persist when market conditions change. This position spawns the need for cover for the 'excess claims' from policies written on a claims made basis for professionals who have ceased to practice because of retirement or for other reasons. The underwriting of such business is perhaps more difficult than the underwriting of business on an occurrence basis.

An understanding of the legal background to the process of claims settlement in the U.S.A. is essential. Whilst as with other territories the vast majority of claims are settled out of court, it is court settlements which dictate the level of claims settlements. Many features of the U.S.A. system lead to higher claims settlements and increased expenses of settlement compared to other territories. The use of juries to award damages, the contingent fee system of engaging lawyers, the use of class actions where there are many similar claims against a single individual or corporation, the concept of joint and several liability in an action for damages and the possibility of the award of punitive damages are each discussed. The influence of no fault legislation on the level of damages for workers compensation is discussed.

The nature of case estimates for outstanding claims and IBNR reserves is different in the U.S.A., in part because of the much longer involvement of actuaries in non-life business. The high level of claims handling and settlement expenses means that it is vital that indemnity payments and expenses are considered separately in nearly all circumstances. The complex nature of these reserving problems is illustrated by a detailed discussion of industrial claims. The alternative bases for determining reserves are described and simple models to estimate IBNR reserves are outlined. 